\title{
Let-7g and $m i R-21$ expression in non-small cell lung cancer: Correlation with clinicopathological and molecular features
}

\author{
ALESSANDRA CAPODANNO ${ }^{1}$, LAURA BOLDRINI ${ }^{1}$, AGNESE PROIETTI $^{1}$, GRETA ALİ ${ }^{2}$, \\ SERENA PELLICCIONI ${ }^{2}$, CRISTINA NICCOLI ${ }^{1}$, ARMIDA D'INCECCO ${ }^{5}$, FEDERICO CAPPUZZO ${ }^{5}$, \\ ANTONIO CHELLA ${ }^{3}$, MARCO LUCCHI ${ }^{4}$, ALFREDO MUSSI ${ }^{1}$ and GABRIELLA FONTANINI ${ }^{1}$ \\ ${ }^{1}$ Department of Surgical, Medical, Molecular Pathology and Critical Area, University of Pisa; \\ ${ }^{2}$ Unit of Pathological Anatomy III, ${ }^{3}$ Division of Pneumology II, ${ }^{4}$ Unit of Thoracic Surgery, \\ A.O.U.P., I-56126 Pisa; ${ }^{5}$ Unit of Medical Oncology, Civil Hospital, I-57125 Livorno, Italy
}

Received April 7, 2013; Accepted May 17, 2013

DOI: 10.3892/ijo.2013.2003

\begin{abstract}
MicroRNAs (miRNAs) play a key role in cancer pathogenesis and are involved in several human cancers, including non-small cell lung cancer (NSCLC). This study evaluated $L e t-7 g$ and $m i R-21$ expression by quantitative realtime PCR in 80 NSCLC patients and correlated the results with their main clinicopathological and molecular features. MiR-21 expression was significantly higher in NSCLC tissues compared to non-cancer lung tissues $(\mathrm{p}<0.0001)$, while no significant changes in Let- $7 g$ expression were observed between the tumor and normal lung tissues. Target prediction analysis led to the identification of $26 \mathrm{miR}-21$ and $24 \mathrm{Let}-7 \mathrm{~g}$ putative target genes that play important roles in cancer pathogenesis and progression. No significant association was observed between the analysed miRNAs and the main clinicopathological or molecular characteristics of the NSCLC patients, although both miRNAs were downregulated in squamous cell carcinomas compared to adenocarcinomas. Noteworthy, we observed a significant association between low Let-7g expression and metastatic lymph nodes at diagnosis $(\mathrm{p}=0.046)$, as well as between high $m i R-21$ expression and $K$-Ras mutations $(\mathrm{p}=0.0003)$. Survival analysis did not show any significant correlation between prognosis and the analysed miRNAs, although the patients with a high Let-7g and $m i R$-2l expression showed a significantly lower short-term progression-free survival $(\mathrm{p}=0.01$ and $\mathrm{p}=0.0003$, respectively) and overall survival ( $\mathrm{p}=0.023$ and $\mathrm{p}=0.0045$, respectively). In conclusion, we showed that Let-7g and miR-21 expression was deregulated in NSCLC and we demonstrated a strong relationship between $m i R-21$ overexpression and $K$-Ras mutations. Our data indicate that $L e t-7 g$ and $m i R-21$ profiling combined with the determination of $K$-Ras mutational status may be
\end{abstract}

Correspondence to: Professor Gabriella Fontanini, Department of Surgical, Medical, Molecular Pathology and Critical Area, University of Pisa, Via Roma 57, I-56126 Pisa, Italy

E-mail: gabriella.fontanini@med.unipi.it

Key words: non-small cell lung cancer, miR-21, Let-7g, K-Ras, biomarker, prognosis considered a useful biomarker for a more effective molecular characterization and clinical management of NSCLC patients.

\section{Introduction}

Lung cancer is the leading cause of cancer-related mortality worldwide (1) and $85 \%$ of the cases are represented by nonsmall cell lung cancer (NSCLC), which is classified into three different histological subtypes: adenocarcinoma (ADC), squamous cell carcinoma (SCC) and large cell carcinoma (LCC) (2-4). Despite a better understanding of the NSCLC pathogenesis and significant improvement in early diagnosis and treatment, the overall 5-year survival is extremely low $(\sim 15 \%)$ and the patients show high recurrence rates even at the early disease stages (1-7), highlighting the necessity of a deeper knowledge of NSCLC biology and the identification of more effective biomarkers.

MicroRNAs (miRNAs) are a highly conserved family of small (17-22 nucleotides), non-coding, endogenous, singlestranded RNA molecules that negatively regulate gene expression by binding to complementary sequences on target messenger RNA (mRNA) $(8,9)$. Recently, miRNAs have been shown to regulate essential cell processes, such as cell proliferation, differentiation, apoptosis, development and metabolism (9-11), and to play a key role in cancer pathogenesis (12-16). Moreover, a miRNA prognostic and diagnostic value has been reported in several malignancies, including lung cancer (14-16).

The first reported miRNA aberrantly expressed in lung cancer was the Let-7 family (17). A reduced Let-7 expression has been significantly correlated with a short post-operative survival in the NSCLC patients (17). Moreover, the ectopic Let-7 expression inhibits cell proliferation in human NSCLC cell lines (18) and reduces tumor burden in mouse NSCLC xenografts (19). Let-7 family members have been demonstrated to behave as tumor suppressor genes and to functionally inhibit several cell cycle regulators and oncogenes, such as Ras family, c-Myc and HMGA2 genes, whose 3'UTRs show multiple Let-7 binding sites $(13,20,21)$.

Conversely, a role as oncogene has been suggested for $m i R-21$ that is deregulated in glioblastoma and lung cancer (22-25). A $m i R-21$ overexpression has been suggested to be an 
independent negative prognostic factor for the overall survival in NSCLC patients (23) and to be related to the lung carcinogenesis in never smokers (26). Several mRNAs have been identified as $m i R-21$ targets, including PDCD4, PTEN, TGF- $\beta$ and $M M P 9$ genes $(22,27)$.

The aim of this study was to evaluate $L e t-7 g$ and $m i R-21$ expression in a series of 80 NSCLC patients to establish their involvement in the NSCLC pathogenesis and their potential diagnostic, prognostic and predictive value.

\section{Materials and methods}

Patients. Eighty NSCLC patients were retrospectively selected from patients who had undergone surgery at the Unit of Thoracic Surgery of the A.O.U.P. between 2005 and 2012. Histological diagnoses were independently formulated by two pathologists (G.F. and G.A.) according to the World Health Organization classification (2-4) and discrepant diagnoses were re-evaluated and discussed until an agreement was reached. Clinicopathological characteristics were collected whenever available for all the patients, while detailed clinical data were obtained only for 55 patients. The study was approved by the local Ethics Committee and all the patients gave their informed consent to the molecular analyses.

DNA and RNA isolation. DNA and RNA were isolated from $10-\mu \mathrm{m}$ sections of formalin-fixed and paraffin-embedded (FFPE) tissues or cytological specimens after manual tumor macrodissection using the QIAamp DNA Mini kit (Qiagen) and miRNeasy FFPE kit (Qiagen), respectively, according to the manufacturer's instructions.

MiRNA expression. Quantification of Let-7g,miR-21 and RNU6B expression was carried out in triplicate into 80 NSCLC and 27 non-cancer lung tissues using specific TaqMan ${ }^{\circledR}$ MicroRNA assays (Applied Biosystems) according to the manufacturer's instructions. Briefly, $10 \mathrm{ng}$ of total RNA were retro-transcribed by the TaqMan MicroRNA Reverse Transcription (RT) kit (Applied Biosystems) and $1.3 \mu \mathrm{l}$ of RT product were analysed by quantitative real-time PCR (qRT-PCR) on the Rotor-Gene 6000 (Corbett Research). Threshold cycle $(\mathrm{Ct})$ and baselines were determined by manual settings. MiRNA expression was calculated by relative quantification and fold expression changes were determined by the $2^{-\Delta \Delta \mathrm{Ct}}$ method using the DataAssist ${ }^{\mathrm{TM}}$ software (Applied Biosystems).

Target prediction and pathway analysis. Let- $7 g$ and $m i R-21$ target genes were predicted by four different miRNA target prediction algorithms: miRanda (http://www.microrna.org/ microrna), TargetScan (http://www.targetscan.org), Pictar (http://www.pictar.org) and miRDB (http://www.mirdb. org). Gene ontology classification and pathway analysis were performed using the PANTHER software (http://www.pantherdb.org).

Mutational analysis. K-Ras gene (Reference sequence: ENSG00000133703) status in codons 12 and 13 was analyzed by pyrosequencing using the Anti-EGFR MoAb response ${ }^{\circledR}$ kit (K-Ras status) (Diatech Pharmacogenetics) according to the manufacturer's instructions.
PCR-single stranded conformation polymorphism (PCR-SSCP) and sequencing analysis were used for genotyping exons 18-21 of the EGFR gene (Reference sequence: ENSG00000146648). The primer sequences were as follows: exon 18, 5'-CTCTGTGTTCTTGTCCCCCC-3' (forward) and 5'-GCCTGTGCCAGGGACCTTAC-3' (reverse); exon 19, 5'-CATGTGGCACCATCTCACA-3' (forward) and 5'-CCACA CAGCAAAGCAGAAAC-3' (reverse); exon 20, 5'-CACACTG ACGTGCCTCTCC-3' (forward) and 5'-TATCTCCCCT CCCCGTATCT-3' (reverse); exon 21, 5'-CCTCACAGCAGG GTCTTCTC-3' (forward) and 5'-CCTGGTGTCAGGAAA ATGCT-3' (reverse). Briefly, 100 ng of DNA were amplified by PCR using the FastStart Taq DNA Polymerase (Roche Diagnostics) on the T3000 Thermocycler 48 (Biometra), as follows: $4 \mathrm{~min}$ at $95^{\circ} \mathrm{C}, 40$ cycles at $95^{\circ} \mathrm{C}$ for $30 \mathrm{sec}, 58^{\circ} \mathrm{C}$ for $30 \mathrm{sec}$ and $72^{\circ} \mathrm{C}$ for $45 \mathrm{sec}$ and $10 \mathrm{~min}$ at $72^{\circ} \mathrm{C}$. PCR products were mixed with an equivalent formamide volume, denatured at $95^{\circ} \mathrm{C}$ for $5 \mathrm{~min}$ and run onto a non-denaturing $12.5 \%$ polyacrylamide gel (GE Healthcare) at $18^{\circ} \mathrm{C}$ and constant $25 \mathrm{~mA}$ for $1 \mathrm{~h}$ and $40 \mathrm{~min}$. Denaturated DNA was visualized by the PlusOne DNA silver staining kit (GE Healthcare) and samples with altered mobility patterns were sequenced as previously described (28).

Statistical analysis. One-way analysis of variance and $\chi^{2}$ test were used to determine the association between miRNA expression and the different parameters, while survival analysis was performed by the Kaplan-Meier method. Statistical analyses were performed using the JMP10 software (SAS) and a two-tailed $\mathrm{p}<0.05$ was considered statistically significant.

\section{Results}

Patient characteristics. This study was conducted in 80 patients with NSCLC, including 55 ADCs, 21 SCCs, 2 LCCs and 2 undifferentiated NSCLCs. The median age at diagnosis was 67 years (range 46-85) and the median follow-up was 32 months (range 7-98). Disease progression with distant and/or loco-regional recurrence and death from lung cancer were observed in $34(61.8 \%)$ and $14(25.5 \%)$ of the 55 NSCLC patients, respectively. The median progression-free survival (PFS) and overall survival (OS) were 18 months (95\% CI, 14-24) and 24 months (95\% CI, 18-30), respectively.

Let-7g and miR-21 expression profile. We quantified the mature Let-7g and $m i R-21$ expression normalized to the $R N U 6 B$ endogenous control in 80 NSCLC and 27 non-cancer lung tissues. The unsupervised hierarchical clustering analysis of miRNA expression using the Euclidean distance as a similarity measure and average linkage algorithm revealed two major clusters based on similarities in miR-21 expression that clearly separated the tumor from non-cancer tissues. On the contrary, we did not observe a clear separation between tumor and normal samples based on Let-7g expression (Fig. 1A).

Let-7g was barely detectable in lung tissues and we did not observe any significant difference between the NSCLC and normal samples $(-0.897 \pm 0.148$ vs. $-0.709 \pm 0.168$, $p=0.585$, Fig. 1B). Conversely, a highly significant increase in $m i R-21$ expression was observed in the NSCLC tissues compared to the non-cancer ones $(4.842 \pm 0.163$ vs. $2.509 \pm 0.182, p<0.0001$, Fig. 1C). 
A

B

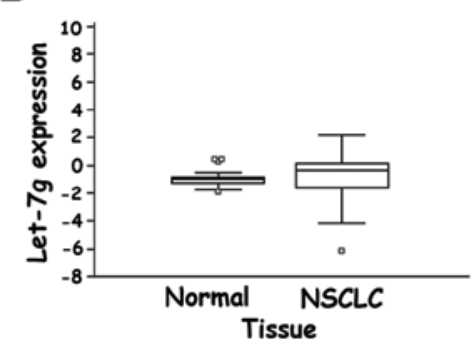

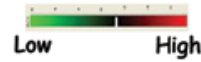

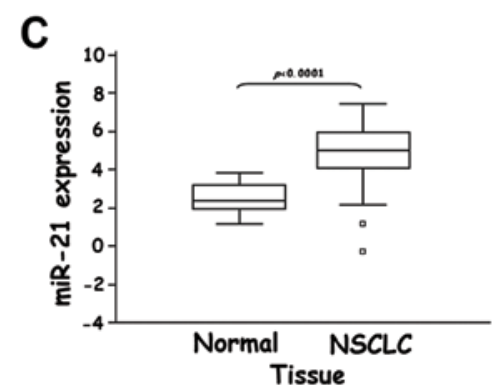

Figure 1.Let-7g and $m i R$-21 expression. (A) Unsupervised hierarchical cluster analysis of miRNA expression in NSCLC tissues (AD samples) versus non-cancer lung tissues (N samples). Box and Whisker plots of Let-7g (B) and miR-21 (C) expression in NSCLC tissues compared to non-cancer lung tissues. Values of Let-7g and $m i R-21$ expression normalized to $R N U 6 B$ endogenous control are reported as $\log _{2} 2^{-\Delta C t}$.
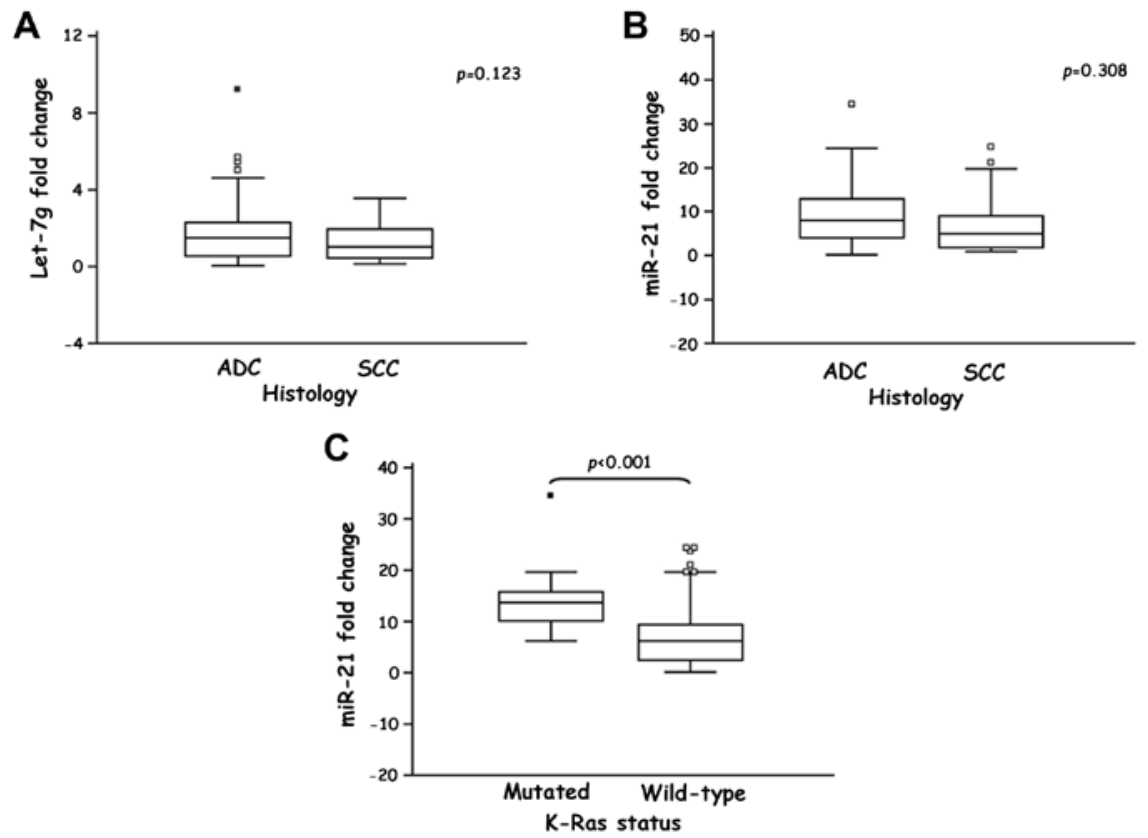

Figure 2. Box and Whisker plots of the differential Let-7g (A) and $m i R-21$ (B and C) expression in relation to the main NSCLC histological subtypes (A and B) and $K$-Ras mutational status (C) in the NSCLC patients. Values of Let-7g and $m i R$ - 21 expression are reported as fold-change of the target miRNA relative expression relatively to a pool of non-cancer lung tissues after normalization to the endogenous control RNU6B.

MiRNA profile and clinicopathological characteristics. To determine whether miRNA profile was correlated with the main clinicopathological characteristics, the NSCLC patients were divided into Let-7g and $m i R-21$ high and low expression groups based on the median fold-change values $(1.315 \pm 0.175$ for Let-7g and 6.964 \pm 0.759 for $m i R-21$ ). Except for a significant association between the low Let- $7 g$ expression and metastatic lymph node presence at diagnosis ( $\mathrm{p}=0.046)$, no other statistically significant associations were observed between the analysed miRNA and the main clinicopathological characteristics of the NSCLC patients (Table I). Interestingly, both Let-7g and $m i R-21$ were upregulated in ADCs compared to SCCs, although these relationships were not statistically significant (Fig. 2A and B). 
Table I. Correlations between the Let-7g and $m i R-21$ expression and the main clinicopathological characteristics of the NSCLC patients.

\begin{tabular}{|c|c|c|c|c|c|c|}
\hline \multirow[b]{2}{*}{ Characteristic } & \multicolumn{2}{|c|}{ Let- $7 g$ expression ${ }^{\mathrm{a}}$} & \multirow[b]{2}{*}{$\mathrm{p}$-value ${ }^{\mathrm{b}}$} & \multicolumn{2}{|c|}{$m i R-21$ expression $^{\mathrm{a}}$} & \multirow[b]{2}{*}{$\mathrm{p}$-value ${ }^{\mathrm{b}}$} \\
\hline & Low & High & & Low & High & \\
\hline \multicolumn{7}{|l|}{ Age } \\
\hline$\leq 67$ years & $22(57.9)$ & $16(42.1)$ & 0.263 & $19 \quad(50)$ & $19 \quad(50)$ & 0.823 \\
\hline$>67$ years & $18(42.8)$ & $24(57.2)$ & & $21 \quad(50)$ & $21 \quad(50)$ & \\
\hline \multicolumn{7}{|l|}{ Gender } \\
\hline Males & $28(50.9)$ & $27(49.1)$ & 0.809 & $27(49.1)$ & $28(50.9)$ & 0.809 \\
\hline Females & $12 \quad(48)$ & $13 \quad(52)$ & & $13 \quad(52)$ & $12 \quad(48)$ & \\
\hline \multicolumn{7}{|l|}{ Histology } \\
\hline $\mathrm{ADC}$ & $27(49.1)$ & $28(50.9)$ & 0.157 & $24(43.6)$ & $31(56.4)$ & 0.065 \\
\hline $\mathrm{SCC}$ & $13(61.9)$ & $8(38.1)$ & & $14(66.7)$ & $7(33.3)$ & \\
\hline $\mathrm{LCC}$ & $0 \quad(0)$ & $2(100)$ & & $2(100)$ & $\begin{array}{ll}0 & (0)\end{array}$ & \\
\hline Others & $0 \quad(0)$ & $2(100)$ & & $0 \quad(0)$ & $2(100)$ & \\
\hline \multicolumn{7}{|l|}{ Tumor stage } \\
\hline T1 (T1a-T1b) & $6 \quad(50)$ & $6 \quad(50)$ & 0.111 & $5(41.7)$ & $7(58.3)$ & 0.793 \\
\hline $\mathrm{T} 2(\mathrm{~T} 2 \mathrm{a}-\mathrm{T} 2 \mathrm{~b})$ & $16(51.6)$ & $15(48.4)$ & & $13(41.9)$ & $18(58.1)$ & \\
\hline $\mathrm{T} 3$ & $2(14.3)$ & $12(85.7)$ & & $8(57.2)$ & $6(42.8)$ & \\
\hline $\mathrm{T} 4$ & $3 \quad(50)$ & $3 \quad(50)$ & & $3 \quad(50)$ & $3 \quad(50)$ & \\
\hline \multicolumn{7}{|l|}{ Lymph node status } \\
\hline Negative & $4(21.1)$ & $15(78.9)$ & 0.046 & $9(47.4)$ & $10(52.6)$ & 0.633 \\
\hline Positive & $20(52.6)$ & $18(47.4)$ & & $14(36.8)$ & $24(63.2)$ & \\
\hline \multicolumn{7}{|l|}{ Smoking } \\
\hline Never smoking & $7(53.8)$ & $6(46.2)$ & 0.425 & $7(53.8)$ & $6(46.2)$ & 0.872 \\
\hline Former smoking & $17(65.4)$ & $9(34.6)$ & & $16(61.5)$ & $10(38.5)$ & \\
\hline Current smoking & $2(100)$ & $0 \quad(0)$ & & $1 \quad(50)$ & $1 \quad(50)$ & \\
\hline \multicolumn{7}{|l|}{ Performance status } \\
\hline ECOG 0 & $5(45.5)$ & $6(54.5)$ & 0.396 & $5(45.5)$ & $6(54.5)$ & 0.149 \\
\hline ECOG 1 & $20 \quad(69)$ & $9 \quad(31)$ & & $18(62.1)$ & $11(37.9)$ & \\
\hline ECOG 2 & $1 \quad(50)$ & $1 \quad(50)$ & & $2(100)$ & $0 \quad(0)$ & \\
\hline \multicolumn{7}{|l|}{ TKI response } \\
\hline Complete response & $1(100)$ & $0 \quad(0)$ & 0.181 & $1(100)$ & $0 \quad(0)$ & 0.218 \\
\hline Partial response & $13(72.2)$ & $5(27.8)$ & & $10(55.6)$ & $8(44.4)$ & \\
\hline Stable disease & $7 \quad(70)$ & $3 \quad(30)$ & & $6 \quad(60)$ & $4 \quad(40)$ & \\
\hline Progressive disease & $5(55.6)$ & $4(44.4)$ & & $7(77.8)$ & $2(22.2)$ & \\
\hline \multicolumn{7}{|l|}{ Disease recurrence } \\
\hline NED & $10(47.6)$ & $11(52.4)$ & 0.072 & $8(38.1)$ & $13(61.9)$ & 0.189 \\
\hline Recurrence & $20(58.8)$ & $14(41.2)$ & & $21(61.8)$ & $13(38.2)$ & \\
\hline
\end{tabular}

${ }^{a}$ Values are shown as $\mathrm{n}(\%) .{ }^{\mathrm{b}} \mathrm{p}$-values were assessed by $\chi^{2}$ test and significant $\mathrm{p}$-values are in bold. ADC, adenocarcinoma; SCC, squamous cell carcinoma; LCC, large cell carcinoma; ECOG, Eastern Cooperative Oncology Group; TKI, tyrosine kinase inhibitor; NED, no evidence of disease.

MiRNA profile and K-Ras and EGFR status. To investigate whether Let-7g and $m i R-21$ expression was correlated to K-Ras and EGFR mutational status, we performed genotyping in the 80 NSCLC patients, except 2, due to insufficient tissue. $K$-Ras and EGFR mutations were observed in 16 (20.5\%) and 23 $(29.5 \%)$ of the 78 NSCLC patients, respectively (Table II).

$K$-Ras and EGFR mutations were mutually exclusive, observed only in the NSCLC patients with ADC and associ- ated with gender (Table III). As is shown in Table III, EGFR status was also significantly associated with the smoking habit $(\mathrm{p}=0.0086)$, performance status $(\mathrm{p}=0.0008)$ and response to the treatment with EGFR tyrosine kinase inhibitors (TKIs) $(\mathrm{p}=0.0076)$.

Statistical analysis did not show any significant association between EGFR mutations and Let-7g or $m i R-21$ expression, while we found a highly significant association between 
Table II. EGFR and $K$-Ras mutational status in the NSCLC patients.

\begin{tabular}{|c|c|c|c|c|}
\hline Gene & Exon & ID sample & Nucleotide substitution & Amino acid substitution \\
\hline$E G F R$ & 19 & $\mathrm{AD} 20, \mathrm{AD} 23, \mathrm{AD} 24, \mathrm{AD} 26, \mathrm{AD} 32, \mathrm{AD} 39$ & c.2235_2249del & p.E746_A750 \\
\hline$E G F R$ & 19 & $\mathrm{AD} 28, \mathrm{AD} 29, \mathrm{AD} 35, \mathrm{AD} 40$ & c.2236_2250del & p.E746_A750 \\
\hline$E G F R$ & 19 & AD16, AD21, AD37 & c.2237_2255delinsT & p.E746_S752delinsV \\
\hline$E G F R$ & 19 & AD22 & c.2239_2264delinsGCCAA & p.L747_A755delinsAN \\
\hline$E G F R$ & 19 & AD25 & c.2240_2257del & p.L747_P753delinsS \\
\hline$E G F R$ & $19+20$ & AD27 & c.2235_2249del+c.2369C>T & p.E746_A750+p.T790M \\
\hline$E G F R$ & 20 & AD41 & c.2311_2312insGCGTGGACA & p.D770_N771insSVD \\
\hline$E G F R$ & 20 & AD36 & c. $2353 \mathrm{~A}>\mathrm{C}$ & p.T785P \\
\hline$E G F R$ & 21 & AD7 & c. $2570 \mathrm{G}>\mathrm{A}$ & p.G857E \\
\hline$E G F R$ & 21 & AD31, AD33, AD38, AD42 & c. $2573 \mathrm{~T}>\mathrm{G}$ & p.L858R \\
\hline$K-R a s$ & 2 & AD9, AD10, AD15, AD17, AD18, AD44 & c. $34 \mathrm{G}>\mathrm{T}$ & p.G12C \\
\hline$K-R a s$ & 2 & AD65 & c.34_35GG $>\mathrm{TT}$ & p.G12F \\
\hline K-Ras & 2 & $\mathrm{LC} 1, \mathrm{AD} 19, \mathrm{AD} 45, \mathrm{AD} 46$ & c. $35 \mathrm{G}>\mathrm{T}$ & p.G12V \\
\hline$K-R a s$ & 2 & $\mathrm{AD} 1, \mathrm{AD} 14, \mathrm{AD} 62$ & c. $35 \mathrm{G}>\mathrm{C}$ & p.G12A \\
\hline$K-R a s$ & 2 & AD61 & c. $35 \mathrm{G}>\mathrm{A}$ & p.G12D \\
\hline$K-\operatorname{Ras}$ & 2 & AD43 & c.37_38GG $>C C$ & p.G13P \\
\hline
\end{tabular}

$K$-Ras status and $m i R-21$ expression ( $\mathrm{p}=0.0003$, Table III). Noteworthy, a significantly higher $m i R-21$ expression was observed in the NSCLC patients with $K$-Ras-mutated tumors $(14.237 \pm 1.638, \mathrm{p}<0.001)$ compared to the patients with $K-R a s$ wild-type tumors (7.316 \pm 0.792 , Fig. 2C).

miRNA target prediction and pathway analysis. Let-7g and miR-21 target gene analysis by miRanda, TargetScan, Pictar and miRDB prediction algorithms led to the identification of a plethora of putative target genes for these miRNAs. In order to minimize the number of false positives, we recorded a gene as a putative target gene of the analysed miRNAs only if it was predicted by at least two prediction algorithms with a high confidence score. According to these stringent criteria, we identified 24 putative target genes for Let- $7 g$, including $H M G A 2, E R C C 6$ and MAP3K3 genes and 26 putative target genes for $m i R-21$, including PDCD4, MSH2 and SPRY1/ SPRY2 genes (Table IV).

We further investigated the biological consequences of Let-7g and $m i R-21$ aberrant expression grouping the predicted target genes by gene ontology terms. This analysis revealed that most of cell processes regulated by these miRNAs play a key role in cancer pathogenesis and are mainly involved in cell proliferation, apoptosis, DNA repair, cell adhesion and signal transduction pathways (Table IV).

Survival analysis. To evaluate the relationships of Let-7g and $m i R-21$ expression with the prognosis of the NSCLC patients, we performed a survival analysis by the Kaplan-Meier method using the disease recurrence and the overall post-operative survival as end-points. We did not observe any significant difference in PFS and OS of the NSCLC patients with a high
Let-7g or $m i R-21$ expression compared to the patients with a low expression of these miRNAs (Fig. 3). However, we further investigated Let-7g and $m i R-21$ as prognostic indicators by restricting our analysis to the first 30 months of the follow-up to verify a possible short-term prognostic value of Let-7g and $m i R-21$ evaluation. Interestingly, we found that the NSCLC patients with a high Let-7g or $m i R-21$ expression showed a significantly shorter mean PFS and OS compared to the patients with a low expression of these miRNAs (Table V).

\section{Discussion}

Lung cancer is the first cause of death for cancer worldwide and $>80 \%$ of the cases are NSCLC (1-4). Although early diagnosis and patient care have greatly improved in recent years, most of the NSCLC patients show locally advanced or metastatic disease at diagnosis and their prognosis remains extremely poor (1-7). Currently, no appropriate diagnostic biomarker exists for NSCLC, highlighting the need of a better knowledge of its biology to improve prevention, diagnosis and treatment.

MiRNAs are a highly conserved family of small non-coding RNA molecules that negatively regulate gene expression $(8,9)$ and their aberrant expression has been found to play a key role in pathogenesis of several malignancies, including NSCLC (13-16). This study was aimed to evaluate Let-7g and $m i R-21$ expression profile in the NSCLC patients in order to establish their role in NSCLC pathogenesis and their potential diagnostic, prognostic and predictive significance.

We demonstrated that $m i R-21$ expression strongly differentiates the NSCLC from non-cancer lung tissues, while we did not observe any Let-7g discriminative value. In our 
Table III. EGFR and K-Ras status in relation to the main clinicopathological and biological characteristics of the NSCLC patients.

\begin{tabular}{|c|c|c|c|c|c|c|}
\hline \multirow[b]{2}{*}{ Characteristic } & \multicolumn{2}{|c|}{$E G F R$ status $^{\mathrm{a}}$} & \multirow[b]{2}{*}{ p-value ${ }^{b}$} & \multicolumn{2}{|c|}{ K-Ras status ${ }^{\mathrm{a}}$} & \multirow[b]{2}{*}{ p-value ${ }^{b}$} \\
\hline & Wild-type & Mutated & & Wild-type & Mutated & \\
\hline \multicolumn{7}{|l|}{$E G F R$ status } \\
\hline Wild-type & & & & $39(70.9)$ & $16(29.1)$ & \multirow[t]{2}{*}{0.0095} \\
\hline Mutated & & & & $23(100)$ & $0 \quad(0)$ & \\
\hline \multicolumn{7}{|l|}{ Age } \\
\hline$\leq 67$ years & 24 (43.6) & $12(52.2)$ & \multirow[t]{2}{*}{0.6595} & $25(40.3)$ & $11(68.8)$ & \multirow[t]{2}{*}{0.0797} \\
\hline$>67$ years & $31(56.4)$ & $11(47.8)$ & & $37(59.7)$ & $5(31.2)$ & \\
\hline \multicolumn{7}{|l|}{ Gender } \\
\hline Males & $47(85.5)$ & $7(30.4)$ & \multirow[t]{2}{*}{$<0.0001$} & $39(62.9)$ & $15(93.8)$ & \multirow[t]{2}{*}{0.0376} \\
\hline Females & $8(14.5)$ & $16(69.6)$ & & $23(37.1)$ & 1 (6.2) & \\
\hline \multicolumn{7}{|l|}{ Histology } \\
\hline $\mathrm{ADC}$ & $32(58.2)$ & $22(95.7)$ & \multirow[t]{4}{*}{0.0049} & $39(62.9)$ & $15(93.8)$ & \multirow[t]{4}{*}{0.0369} \\
\hline SCC & $20(36.4)$ & $0 \quad(0)$ & & $20(32.3)$ & $\begin{array}{ll}0 & (0)\end{array}$ & \\
\hline $\mathrm{LCC}$ & 2 (3.6) & $0 \quad(0)$ & & $2(3.2)$ & $0 \quad(0)$ & \\
\hline Others & $1(1.8)$ & $1(4.3)$ & & $1(1.6)$ & $1(6.2)$ & \\
\hline \multicolumn{7}{|l|}{ Tumor stage } \\
\hline T1 (T1a-T1b) & $9(20.0)$ & $3(16.7)$ & \multirow[t]{4}{*}{0.1511} & $9(18.4)$ & $3(21.4)$ & \multirow[t]{4}{*}{0.3189} \\
\hline T2 (T2a-T2b) & $20(44.4)$ & $11(61.1)$ & & $27(55.1)$ & $4(28.6)$ & \\
\hline $\mathrm{T} 3$ & $13(28.9)$ & $1(5.5)$ & & $9(18.4)$ & $5(35.7)$ & \\
\hline $\mathrm{T} 4$ & $3(6.7)$ & $3(16.7)$ & & $4(8.1)$ & $2(14.3)$ & \\
\hline \multicolumn{7}{|l|}{ Lymph node status } \\
\hline Negative & $16 \quad(39)$ & $3(18.8)$ & \multirow[t]{2}{*}{0.2516} & $15(34.1)$ & $4(30.8)$ & \multirow[t]{2}{*}{0.9111} \\
\hline Positive & $25 \quad(61)$ & $13(81.2)$ & & $29(65.9)$ & $9(69.2)$ & \\
\hline Smoking & & & & & & \\
\hline Never smoking & $4(15.4)$ & $9 \quad(60)$ & 0.0086 & $12(35.3)$ & $1(14.3)$ & 0.2975 \\
\hline Former smoking & $21(80.8)$ & $5(33.3)$ & & $21(61.8)$ & $5(71.4)$ & \\
\hline Current smoking & 1 (3.8) & $1(6.7)$ & & 1 (2.9) & $1(14.3)$ & \\
\hline Performance status & & & & & & \\
\hline ECOG 0 & $2(18.2)$ & $9(81.8)$ & 0.0008 & $10(90.9)$ & $1(9.1)$ & 0.5509 \\
\hline ECOG 1 & $23(79.3)$ & $6(20.7)$ & & $23(79.3)$ & $6(20.7)$ & \\
\hline ECOG 2 & $2(100)$ & $\begin{array}{ll}0 & (0)\end{array}$ & & 2 (100) & $\begin{array}{ll}0 & (0)\end{array}$ & \\
\hline TKI response & & & & & & \\
\hline Complete response & $0 \quad(0)$ & $1(100)$ & 0.0076 & $1(100)$ & $0 \quad(0)$ & 0.5417 \\
\hline Partial response & $7(38.9)$ & $11(61.1)$ & & $16(88.9)$ & $2(11.1)$ & \\
\hline Stable disease & $9 \quad(90)$ & $1 \quad(10)$ & & $7 \quad(70)$ & $3 \quad(30)$ & \\
\hline Progressive disease & $8(88.9)$ & $1(11.1)$ & & $8(88.9)$ & $1(11.1)$ & \\
\hline Disease recurrence & & & & & & \\
\hline NED & $13(35.1)$ & $7(41.2)$ & 0.9016 & $14(34.1)$ & $6(46.2)$ & 0.6515 \\
\hline Recurrence & $24(64.9)$ & $10(58.8)$ & & $27(65.9)$ & $7(53.8)$ & \\
\hline Let- $7 g$ expression & & & & & & \\
\hline Low & $27(49.1)$ & $11(47.8)$ & 0.8835 & $32(51.6)$ & $6(37.5)$ & 0.4676 \\
\hline High & $28(50.9)$ & $12(52.2)$ & & $30(48.4)$ & $10(62.5)$ & \\
\hline$m i R-21$ expression & & & & & & \\
\hline Low & $27(49.1)$ & $12(52.2)$ & 0.8039 & $38(61.3)$ & $1(6.2)$ & 0.0003 \\
\hline High & $28(50.9)$ & $11(47.8)$ & & $24(38.7)$ & $15(93.8)$ & \\
\hline
\end{tabular}

${ }^{a}$ Values are shown as $\mathrm{n}(\%)$. ${ }^{\mathrm{b}} \mathrm{p}$-values were assessed by $\chi^{2}$ test and significant $\mathrm{p}$-values are in bold. ADC, adenocarcinoma; SCC, squamous cell carcinoma; LCC, large cell carcinoma; ECOG, Eastern Cooperative Oncology Group; TKI, tyrosine kinase inhibitor; NED, no evidence of disease. 
Table IV. Putative target genes of the dysregulated Let-7g and $m i R-21$ in the NSCLC patients.

\begin{tabular}{|c|c|c|c|}
\hline miRNA & Locus & Pathway & Target genes \\
\hline Let $-7 g$ & $3 \mathrm{p} 21.1$ & $\begin{array}{l}\text { Cell cycle } \\
\text { Transcription/transduction } \\
\text { DNA repair } \\
\text { Apoptosis } \\
\text { MAPK/ERK pathway } \\
\text { Insulin/TGF } \beta \text { pathway } \\
\text { PI3K/Akt pathway } \\
\text { Wnt pathway }\end{array}$ & $\begin{array}{l}\text { HMGA2, E2F5, COIL, DNA2, CCNJ, CCND2, CDC25A, LIN28B, BACH1 } \\
\text { BZW1, HIC2 } \\
\text { ERCC6, SMARCAD1, BACH1 } \\
\text { N-MYC, CASP3, MAP4K3 } \\
N-R A S, M A P 3 K 3, M A P 4 K 3, M A P K 6 \\
F O X P 2, I G F 1 R, I G F 2 B P 2 \\
N-R A S, F O X P 2, C C N D 2 \\
\text { END1, END2, N-MYC }\end{array}$ \\
\hline$m i R-21$ & $17 q 23.2$ & $\begin{array}{l}\text { Cell cycle } \\
\text { DNA repair } \\
\text { Apoptosis } \\
\text { Angiogenesis } \\
\text { Proteolysis } \\
\text { Cell adhesion } \\
\text { MAPK/ERK pathway } \\
\text { TGF } \beta \text { pathway } \\
\text { G-protein pathway }\end{array}$ & $\begin{array}{l}\text { STAG2, KIF6 } \\
\text { MSH2, FANCC, CHD7 } \\
\text { PDCD4, APAF1, STAT3, MALT1, SGK3 } \\
\text { SOS2, JAG1, MAP3K1, STAT3 } \\
\text { WWP1 } \\
\text { CCL1, MATN2, TGFBI, VCL } \\
\text { MAP3K1, STAT3, SOS2, NKIRAS1, SPRY1, SPRY2 } \\
\text { BMPR2, SMAD7 } \\
\text { SOS2, TIAM2, GPR64, KRIT1 }\end{array}$ \\
\hline
\end{tabular}
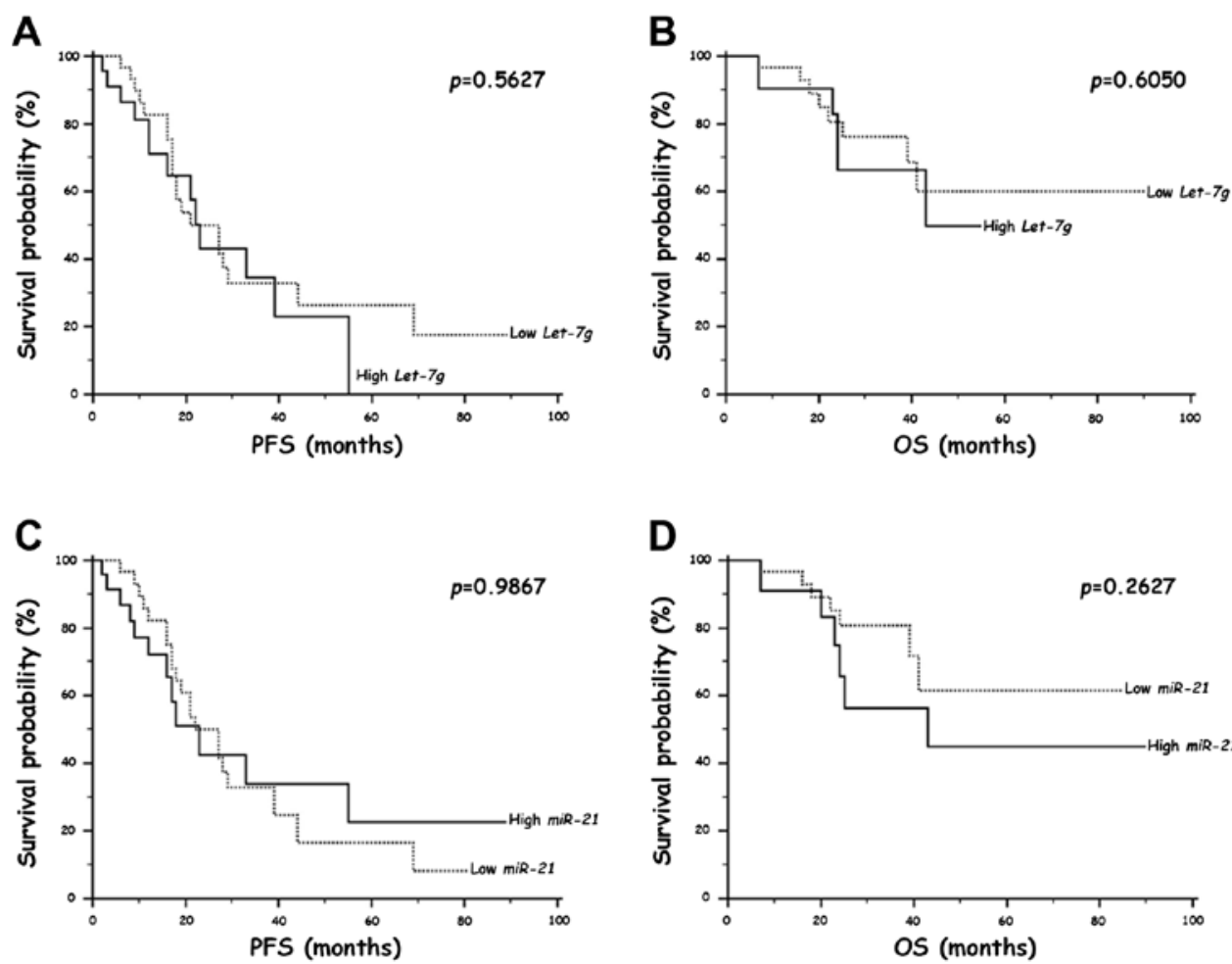

Figure 3. Kaplan-Meier curves in the NSCLC patients with a different Let-7g (A and B) and $m i R-21$ (C and D) expression. PFS, progression-free survival; OS, overall survival.

study, a highly significant increase was found in $m i R-21$ expression in NSCLC tissues compared to the non-cancer ones, in agreement with previous results that demonstrated a $m i R-21$ overexpression in tumor tissues from several human malignancies $(23,29-31)$. Conversely, we observed a reduced Let-7g expression that was expressed at comparable levels in
NSCLC and non-cancer lung tissues. Let-7g downregulation in NSCLC tissues has been previously reported by several authors, who have also demonstrated that the aberrant expression of Let-7 family represents an early event during NSCLC carcinogenesis and is more common in SCCs compared to ADCs $(12,19,32,33)$. In our study, Let-7g and $m i R-21$ are 
Table V. Short-term correlations between the prognosis of the NSCLC patients and the Let-7 and miR-21 expression.

\begin{tabular}{lcccc}
\hline Characteristic & $\begin{array}{c}\text { PFS } \\
(\text { months })^{\mathrm{a}}\end{array}$ & p-value $^{\mathrm{b}}$ & $\begin{array}{c}\text { OS } \\
\text { (months) }\end{array}$ & p-value $^{\mathrm{b}}$ \\
\hline
\end{tabular}

\section{Let-7g}

expression

$\begin{array}{llllll}\text { Low } & 18(15-22) & \mathbf{0 . 0 1} & 20(16-23) & \mathbf{0 . 0 2 3} \\ \text { High } & 12(8-16) & & 13(9-17) & \\ \begin{array}{l}m i R-21 \\ \text { expression }\end{array} & & & & & \\ \text { Low } & 19(16-23) & \mathbf{0 . 0 0 0 3} & 21(17-25) & \mathbf{0 . 0 0 4 5} \\ \text { High } & 11(8-14) & & 13(9-17) & \end{array}$

${ }^{a}$ Values are shown as mean $(95 \% \mathrm{CI})$. ${ }^{\mathrm{b}} \mathrm{p}$-values were assessed by the one-way analysis of variance (ANOVA) and significant p-values are in bold.

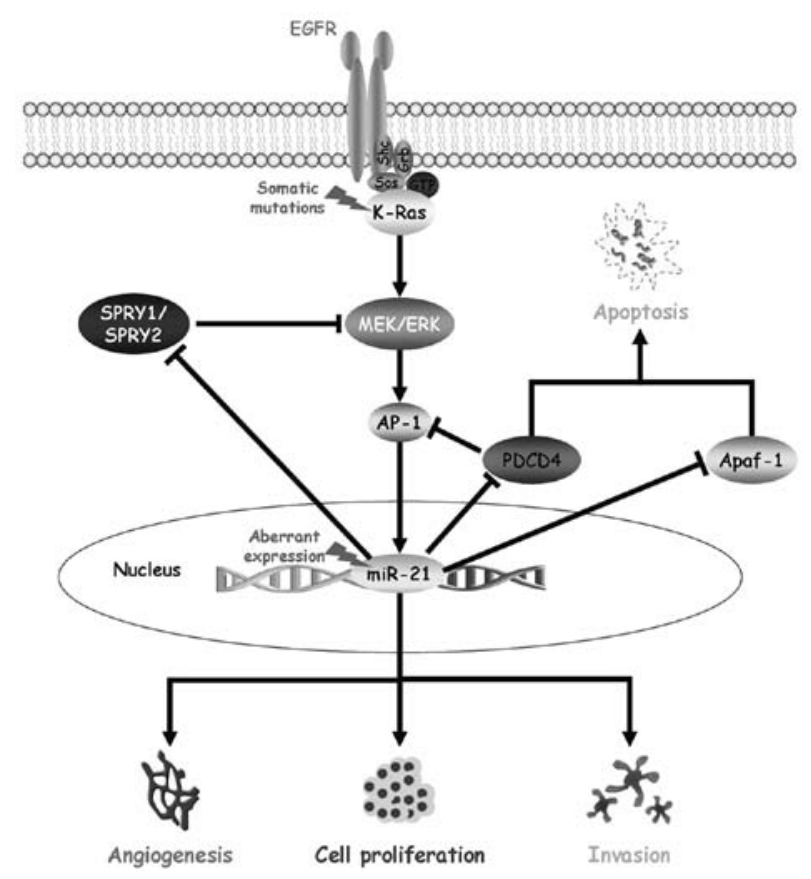

Figure 4. Auto-regulatory loop between $K$-Ras and $m i R-21$. Proposed model showing that $m i R-21$ potentiates the oncogenic $K$-Ras signalling pathway by promoting cell proliferation, angiogenesis and invasion and inhibits apoptosis through the repression of multiple tumor suppressors.

downregulated in SCCs compared to ADCs, but their evaluation has not been shown to have a significant diagnostic value in discriminating between these two different histotypes, as previously reported in larger miRNA profiling studies $(29,30)$. Landi et al (30) reported that Let-7g and $m i R-21$ differential expression allows to discriminate between ADC and SCC in the early-stage tumors (stage I), but not in the advanced stage (stage II-IV), suggesting that miRNA expression loses its histology-specificity in the more advanced and less differentiated tumors. Therefore, the lack of a statistical significance we observed between the altered Let $-7 g$ and $m i R-21$ expression and NSCLC histology could be explained by the fact that most of the enrolled patients were diagnosed in an advanced stage, where miRNA histology-related expression may be not specific.

Concerning the other analysed clinicopathological characteristics, we did not observe any significant correlation between the Let-7g and $m i R-21$ dysregulated expression and the clinicopathological features, including age, tumor stage, therapy response and smoking habit. In particular, our results concerning the relationship between the miR-21 expression and the smoking habit are in disagreement with data reported by Seike et al (26), who demonstrated that $m i R-21$ expression is significantly higher in tumors from smokers than from never smokers; however, this discrepancy could be due to the small number of patients for whom we had smoking data. Interestingly, we found that Let-7g expression is significantly associated with lymph nodal status. We showed that most of the NSCLC patients with a low Let-7g expression present metastatic lymph nodes at diagnosis, while no substantial differences were observed for the patients with a high Let-7g expression. This result suggests an important role of Let-7g in NSCLC tumor progression and acquisition of metastatic potential and is supported by in vivo studies showing that ectopic Let $7 g$ expression in NSCLC xenografts induce a significant decrease in tumor growth and spread $(17,18)$.

Since the importance of EGFR and $K$-Ras mutation detection in current management of the NSCLC patients, we explored the relationship between their mutational status and Let-7g and $m i R-21$ expression profile. In our study, the frequency of $K$-Ras mutation (20.5\%) was in agreement with previously reported data $(34,35)$, whereas $E G F R$ mutation incidence was slightly higher $(29.5 \%)$ than that reported in the literature for lung cancer (15-20\%) (6,36-38), because many of the recruited patients belonged to a larger study designed to evaluate the EGFR TKI response. According to previously reported data $(20,21,30,39)$, Let- $7 g$ expression was not correlated with $E G F R$ or $K$-Ras mutational status. However, several studies have demonstrated that Let-7g acts as a K-Ras negative regulator by binding to multiple sites of their 3'UTRs (40) and that lung cancer tissues with reduced Let-7g levels have significantly higher K-Ras levels compared to their corresponding normal tissues $(18,20)$. Therefore, it is possible that the aberrant expression of Let-7g and K-Ras mutations are mutually exclusive in NSCLC carcinogenesis with a more predominant effect of Let-7g dysregulation in SCCs, which show a low expression of this miRNA compared to the other NSCLC histotypes and a more prominent role of $K$-Ras mutations in ADC carcinogenesis $(32,33)$.

Furthermore, we first demonstrated a strong and highly significant correlation between the high $m i R-21$ expression and the presence of mutations in the codons 12 and 13 of $K$-Ras gene, suggesting a synergistic interplay between $m i R-21$ and $K$-Ras oncogenes that supports neoplastic phenotype in NSCLC. Based on $m i R-21$ expression and target gene prediction results, we might hypothesize an auto-regulatory loop between oncogenic $K$-Ras and $m i R-21$ mediated by the MAPK/ ERK signalling pathway, SPRY1/SPRY2 and PDCD4 (Fig. 4). $K$-Ras mutations determine a constitutive protein activation with a consequent activation of the MAPK/ERK signalling pathway, which plays an important role in lung carcinogenesis by inhibiting apoptosis and promoting cell proliferation, cell 
growth, angiogenesis, invasion and metastasis (41). On the other hand, $m i R-21$ modulates several components critical to the NSCLC pathogenesis by targeting apoptotic effectors and antagonists of the MAPK/ERK signalling pathway $(22,25,27)$. The high $m i R-21$ expression observed in our NSCLC patients might cause a decrease in SPRYI/SPRY2 expression that has been demonstrated to negatively regulate the MAPK/ERK signalling pathway and to enhance cell migration (42). In addition, the negative regulation of PDCD4 and Apaf-1 genes by $m i R-21$ leads to apoptosis inhibition $(22,27,43)$, as well as to the removal of the PDCD4 inhibitory effect on AP-1, which is downstream the MAPK/ERK signalling pathway and promotes $m i R-21$ expression $(44,45)$. This complex and auto-regulatory circuit might justify the high levels of $m i R-21$ expression observed in our study in the NSCLC patients harbouring $K$-Ras mutations and might have a final stimulation effect on the processes that promote tumor progression and therapy resistance (Fig. 4).

We investigated the relationship between the differential Let- $7 g$ and $m i R-21$ expression and prognosis of the NSCLC patients without observing any statistically significant correlation. These results are in disagreement with data reported by other authors that support a negative prognostic role for Let-7g, whose downregulation has been associated with a reduced overall post-operative survival in NSCLC patients (18-21), and $m i R-21$, whose overexpression has been associated with a poor prognosis irrespective of the TNM stage and lymph nodal status $(23,26,46)$. However, these discrepant results could be due to the small number of patients with available clinical data. Interestingly, by restricting our analysis to the first 30 months of the follow-up observation, we demonstrated that the NSCLC patients with a high expression of either Let-7g or $m i R-21$ show a highly significant shorter PFS and OS compared to the patients with a low expression of both these miRNAs, suggesting a possible negative short-term prognostic value of the evaluation of Let-7g and $m i R-21$ expression.

In conclusion, our data show that Let-7g and $m i R-21$ are aberrantly expressed in the NSCLC patients and that there is a close interplay among $K$-Ras, $m i R-21$ and Let- $7 g$ in NSCLC, suggesting that their systematic evaluation could represent a useful biomarker in the molecular characterization and management of NSCLC patients.

\section{References}

1. Siegel R, Naishadham D and Jemal A: Cancer statistics, 2012. CA Cancer J Clin 62: 10-29, 2012.

2. Travis WD, Brambilla E, Muller-Hemerlink HK and Harris CC: World Health Organization Classification of Tumours. Pathology and Genetics of Tumours of the Lung, Pleura, Thymus and Heart. IARC Press, Lyon, 2004.

3. Travis WD, Brambilla E, Noguchi M, Nicholson AG, Geisinger KR, Yatabe Y, Beer DG, Powell CA, Riely GJ, Van Schil PE, Garg K, Austin JH, Asamura H, Rusch VW, Hirsch FR, Scagliotti G, Mitsudomi T, Huber RM, Ishikawa Y, Jett J, Sanchez-Cespedes M, Sculier JP, Takahashi T, Tsuboi M, Vansteenkiste J, Wistuba I, Yang PC, Aberle D, Brambilla C, Flieder D, Franklin W, Gazdar A, Gould M, Hasleton P, Henderson D, Johnson B, Johnson D, Kerr K, Kuriyama K, Lee JS, Miller VA, Petersen I, Roggli V, Rosell R, Saijo N, Thunnissen E, Tsao $M$ and Yankelewitz D: International association for the study of lung cancer/American thoracic society/European respiratory society international multidisciplinary classification of lung adenocarcinoma. J Thorac Oncol 6: 244-285, 2011.
4. Travis WD, Brambilla E, Noguchi M, Nicholson A, Geisinger K, Yatabe Y, Ishikawa Y, Wistuba I, Flieder DB, Franklin W, Gazdar A, Hasleton PS, Henderson DW, Kerr KM, Petersen I, Roggli V, Thunnissen E and Tsao M: Diagnosis of lung cancer in small biopsies and cytology: implications of the 2011 International Association for the Study of Lung Cancer/American Thoracic Society/European Respiratory Society Classification. Arch Pathol Lab Med 137: 668-684, 2012.

5. Bronte G, Rizzo S, La Paglia L, Adamo V, Siragusa S, Ficorella C, Santini D, Bazan V, Colucci G, Gebbia N and Russo A: Driver mutations and differential sensitivity to targeted therapies: a new approach to the treatment of lung adenocarcinoma. Cancer Treat Rev 36: S21-S29, 2010.

6. Pao W and Girard N: New driver mutations in non-small-cell lung cancer. Lancet Oncol 12: 175-180, 2011.

7. Saintigny P and Burger JA: Recent advances in non-small cell lung cancer biology and clinical management. Discov Med 13: 287-297, 2012.

8. He L and Hannon GJ: MicroRNAs: small RNAs with big role in gene regulation. Nat Rev Genet 5: 522-531, 2002.

9. Bartel DP: MicroRNAs: genomics, biogenesis, mechanism and function. Cell 116: 281-297, 2004.

10. Schmittgen TD: Regulation of microRNA processing in development, differentiation and cancer. J Cell Mol Med 12: 1811-1819, 2008.

11. Huang Y, Shen XJ, Zou Q, Wang SP, Tang SM and Zhang GZ: Biological functions of microRNAs: a review. J Physiol Biochem 67: 129-139, 2011.

12. Calin GA, Sevignani C, Dumitru CD, Hyslop T, Noch E, Yendamuri S, Shimizu M, Rattan S, Bullrich F, Negrini M and Croce CM: Human microRNA genes are frequently located at fragile sites and genomic regions involved in cancers. Proc Natl Acad Sci USA 101: 2999-3004, 2004.

13. Zhang B, Pan X, Cobb GP and Anderson TA: microRNAs as oncogenes and tumor suppressors. Dev Biol 302: 1-12, 2007.

14. Bartels CL and Tsongalis GJ: MicroRNAs: novel biomarkers for human cancer. Clin Chem 55: 623-631, 2009.

15. Farazi TA, Spitzer JI, Morozov P and Tuschl T: miRNAs in human cancer. J Pathol 223: 102-115, 2011.

16. Iorio MV and Croce CM: MicroRNA dysregulation in cancer: diagnostics, monitoring and therapeutics. A comprehensive review. EMBO Mol Med 4: 143-159, 2012.

17. Takamizawa J, Konishi H, Yanagisawa K, Tomida S, Osada H, Endoh H, Harano T, Yatabe Y, Nagino M, Nimura Y, Mitsudomi T and Takahashi T: Reduced expression of the let-7 microRNAs in human lung cancers in association with shortened postoperative survival. Cancer Res 64: 3753-3756, 2004.

18. Johnson CD, Esquela-Kerscher A, Stefani G, Byrom M, Kelnar K, Ovcharenko D, Wilson M, Wang X, Shelton J, Shingara J, Chin L, Brown D and Slack FJ: The let-7 microRNA represses cell proliferation pathways in human cells. Cancer Res 67: 7713-7722, 2007.

19. Kumar MS, Erkeland SJ, Pester RE, Chen CY, Ebert MS, Sharp PA and Jacks T: Suppression of non-small cell lung tumor development by the let-7 microRNA family. Proc Natl Acad Sci USA 105: 3903-3908, 2008.

20. Johnson SM, Grosshans H, Shingara J, Byrom M, Jarvis R, Cheng A, Labourier E, Reinert KL, Brown D and Slack FJ: RAS is regulated by the let-7 microRNA family. Cell 120: 635-647, 2005 .

21. Roush S and Slack FJ: The let-7 family of microRNAs. Trends Cell Biol 18: 505-516, 2008.

22. Krichevsky AM and Gabriely G: miR-21: a small multi-faceted RNA: J Cell Mol Med 13: 39-53, 2009.

23. Gao W, Yu Y, Cao H, Shen H, Li X, Pan S and Shu Y: Deregulated expression of miR-21, miR-143 and miR-181a in non small cell lung cancer is related to clinicopathologic characteristics or patient prognosis. Biomed Pharmacother 64: 399-408, 2010.

24. Moore LM and Zhang W: Targeting miR-21 in glioma: a small RNA with big potential. Expert Opin Ther Targets 14: 1247-1257, 2010.

25. Pan X, Wang ZX and Wang R: MicroRNA-21: a novel therapeutic target in human cancer. Cancer Biol Ther 10: 1224-1232, 2011.

26. Seike M, Goto A, Okano T, Bowman ED, Schetter AJ, Horikawa I, Mathe EA, Jen J, Yang P, Sugimura H, Gemma A, Kudoh S, Croce CM and Harris CC: MiR-21 is an EGFR-regulated antiapoptotic factor in lung cancer in never-smokers. Proc Natl Acad Sci USA 106: 12085-12090, 2009.

27. Selcuklu SD, Donoghue MT and Spillane C: miR-21 as a key regulator of oncogenic processes. Biochem Soc Trans 37: 918-925, 2009. 
28. Capodanno A, Boldrini L, Alì G, Pelliccioni S, Mussi A and Fontanini G: Phosphatidylinositol-3-kinase $\alpha$ catalytic subunit gene somatic mutations in bronchopulmonary neuroendocrine tumours. Oncol Rep 28: 1559-1566, 2012.

29. Volinia S, Calin GA, Liu CG, Ambs S, Cimmino A, Petrocca F, Visone R, Iorio M, Roldo C, Ferracin M, Prueitt RL, Yanaihara N, Lanza G, Scarpa A, Vecchione A, Negrini M, Harris CC and Croce CM: A microRNA expression signature of human solid tumors defines cancer gene targets. Proc Natl Acad Sci USA 103: 2257-2261, 2006.

30. Landi MT, Zhao Y, Rotunno M, Koshiol J, Liu H, Bergen AW, Rubagotti M, Goldstein AM, Linnoila I, Marincola FM, Tucker MA, Bertazzi PA, Pesatori AC, Caporaso NE, McShane LM and Wang E: MicroRNA expression differentiates histology and predicts survival of lung cancer. Clin Cancer Res 16: 430-441, 2010 .

31. Meng F, Henson R, Wehbe-Janek H, Ghoshal K, Jacob ST and Patel T: MicroRNA-21regulates expression of the PTEN tumor suppressor gene in human hepatocellular cancer. Gastroenterology 133: 647-658, 2007.

32. Mitsudomi T, Oyama T, Nishida K, Ogami A, Osaki T, Sugio K, Yasumoto K, Sugimachi K and Gazdar AF: Loss of heterozygosity at $3 p$ in non-small cell lung cancer and its prognostic implication. Clin Cancer Res 2: 1185-1189, 1996.

33. Zabarovsky ER, Lerman MI and Minna JD: Tumor suppressor genes on chromosome $3 p$ involved in the pathogenesis of lung and other cancers. Oncogene 21: 6915-6935, 2002.

34. Riely GJ, Marks J and Pao W: KRAS mutations in non-small cell lung cancer. Proc Am Thorac Soc 6: 201-205, 2009.

35. Mao C, Qiu LX, Liao RY, Du FB, Ding H, Yang WC, Li J and Chen Q: KRAS mutations and resistance to EGFR-TKIs treatment in patients with non-small cell lung cancer: a metaanalysis of 22 studies. Lung Cancer 69: 272-278, 2010.

36. Yatabe $\mathrm{Y}$ and Mitsudomi T: Epidermal growth factor receptor mutations in lung cancers. Pathol Int 57: 233-244, 2007.

37. Ladanyi $\mathrm{M}$ and Pao W: Lung adenocarcinoma: guiding EGFRtargeted therapy and beyond. Mod Pathol 21: S16-S22, 2008.

38. Dacic S: Molecular diagnostics of lung carcinomas. Arch Pathol Lab Med 135: 622-629, 2011.
39. Dacic S, Kelly L, Shuai Y and Nikiforova MN: miRNA expression profiling of lung adenocarcinomas: correlation with mutational status. Mod Pathol 23: 1577-1582, 2010.

40. Chin LJ, Ratner E, Leng S, Zhai R, Nallur S, Babar I, Muller RU, Straka E, Su L, Burki EA, Crowell RE, Patel R, Kulkarni T, Homer R, Zelterman D, Kidd KK, Zhu Y, Christiani DC, Belinsky SA, Slack FJ and Weidhaas JB: A SNP in a let-7 microRNA complementary site in the KRAS $3^{\prime}$ untranslated region increases non-small cell lung cancer risk. Cancer Res 68: 8535-8540, 2008.

41. Boutros T, Chevet E and Metrakos P: Mitogen-activated protein (MAP) kinase/MAP kinase phosphatase regulation: roles in cell growth, death and cancer. Pharmacol Rev 60: 261-310, 2008.

42. Hatley ME, Patrick DM, Garcia MR, Richardson JA, Bassel-Duby R, van Rooij E and Olson EN: Modulation of K-Ras-dependent lung tumorigenesis by MicroRNA-21. Cancer Cell 18: 282-293, 2010.

43. Lu Z, Liu M, Stribinskis V, Klinge CM, Ramos KS, Colburn NH and Li Y: MicroRNA-21 promotes cell transformation by targeting the programmed cell death 4 gene. Oncogene 27: 4373-4379, 2008.

44. Hwang SK, Jin H, Kwon JT, Chang SH, Kim TH, Cho CS, Lee KH, Young MR, Colburn NH, Beck GR Jr, Yang HS and Cho MH: Aerosol-delivered programmed cell death 4 enhanced apoptosis, controlled cell cycle and suppressed AP-1 activity in the lungs of AP-1 luciferase reporter mice. Gene Ther 14: 1353-1361, 2007.

45. Talotta F, Cimmino A, Matarazzo MR, Casalino L, De Vita G, D'Esposito M, Di Lauro R and Verde P: An autoregulatory loop mediated by miR-21 and PDCD 4 controls the AP-1 activity in RAS transformation. Oncogene 28: 73-84, 2009.

46. Markou A, Tsaroucha EG, Kaklamanis L, Fotinou M, Georgoulias V and Lianidou ES: Prognostic value of mature microRNA-21 and microRNA-205 overexpression in non-small cell lung cancer by quantitative real-time RT-PCR. Clin Chem 54: 1696-1704, 2008. 